\title{
Harvesters Palsy: An Electrophysiological Study
}

\author{
Naresh Kumar ${ }^{1}$, Kirti Sharma ${ }^{1}$, Sibadatta Das ${ }^{1}$, Manjeet Singh ${ }^{2}$ and Amit Saxena ${ }^{3}$ \\ ${ }^{1}$ Physiology, SHKM Government Medical College, India \\ ${ }^{2}$ Physiology, BPS Government Medical College, India \\ ${ }^{3}$ Anatomy, SGT Medical College, India
}

*Corresponding author: Kirti Sharma, Demonstrator, SHKM GMC Nalhar, Nuh, Haryana, India

Submission: January 26, 2018; Published: March 08, 2018

\begin{abstract}
A unique phenomenon was observed in the neurodiagnostic lab of Post Graduate Institute of Medical Sciences Rohtak, Haryana, India during the harvesting season of wheat crop, where a few patients came with footdrop giving similar type of history that they were working in the fields in squatting position for harvesting continously for 5-8 hours per day since last 10-20 days without taking a break of more than half an hour. A total of twelve such farmers were examined. Nerve conduction studies were done by using equipment Recorders and Medicare Systems- Electromyography EP Mark-II Chandigarh. Out of these twelve farmers, ten were having footdrop on right side, while two were having on the left side confirmed by neurological examination. Nerve conduction studies showed reduced motor nerve conduction velocity and amplitude of peroneal nerve on affected side, while latency was increased on that side. By this study, it was concluded that peroneal neuropathy is the most common cause of footdrop in farmers doing harvesting manually.
\end{abstract}

Keywords: Harvesters palsy; Peroneal nerve; Footdrop; Nerve conduction velocity; Farmer

Abbreviations: PGIMS: ;RMS-EMG: ; MNCV: ; NCV

\section{Introduction}

The most common neuropathy found in the lower limb is peroneal neuropathy and ranked 3rd most commonly found neuropathy after median and ulnar neuropathies [1,2]. Weakness of the extensor muscle of foot, also known as foot drop can be caused by various pathologies at different levels of the central and peripheral nervous system. It may be due to lesions of spinal cord, nerve roots or peripheral nerves. But most vulnerable to trauma is the common peroneal nerve due to its closeness to the surface [3]. Ankle dorsiflexion weakness due to peroneal nerve palsy may be the initial presenting symptom of certain generalised disorders such as amyotrophic lateral sclerosis or a hereditary neuropathy [1].

Sciatic nerve after taking origin from sacral plexus divides into two branches i.e. common peroneal and tibial nerve, proximal to the poplitial fossa [4]. The common peroneal nerve passes along the lateral border of the poplitial fossa and reaches at the back of the head of the fibula. After winding round the neck of fibula, it divides into superficial and deep peroneal nerves [5]. Vast majority of lesions of peroneal nerve are traumatic in origin either due to traction, laceration or compression [6,7]. Peroneal neuropathy occurring during weight reduction leading to foot drop is also known as slimmers palsy [8]. In cases of farmers, lesions of the peroneal nerve at fibular head commonly involves the deep branch rather than the whole nerve [9]. Chronic squatting and prolonged sitting in the cross legged position are the common causes of compression of peroneal nerve other than that of postoperative procedures [10]. Lee suggested that by recording the compound nerve action potential of common peroneal nerve at fibular neck, the precise location of the lesion of the nerve i.e. whether at fibular head or distal to the fibular neck can be ruled out [7]. Only a few studies are available to know the cause of footdrop in farmers by electrodiagnostic methods $[10,11]$.

\section{Materials and Methods}

A unique phenomenon was observed in the neurodiagnostic lab of Post Graduate Institute of Medical Sciences (PGIMS) Rohtak, Haryana, India during the harvesting season of wheat, where a few patients came with footdrop giving similar type of history that they were working in the fields in squatting position for harvesting continuously for 5-8 hours per day since last 10-20 days without taking a break of more than half hour.

A total of twelve such farmers were examined with a mean age of $24 \pm 8.5$ years having history of unilateral foot drop reffered to our electrophysiology lab through orthopaedics department at PGIMS Rohtak. The possibility of diabetes mellitus or polyneuropathy was ruled out by taking clinical history and blood/ urine sugar tests. Patients were neurologically examined to rule out any cause of footdrop other than peroneal nerve injury at the fibular head. 
Nerve conduction studies were done by using equipment Recorders and Medicare Systems-Electromyography (RMS-EMG) EP Mark-II Chandigarh. The room temperature was kept between $24 \mathrm{oC}$ and 28oC. Supramaximal stimulus over and above the duration of 50-1000 microseconds and a current of 0-100 milliampere was given to get sufficient response. Stimulus was given at three points, first at ankle between the tendons of tibialis anterior and extensor hallusis longus muscles, second was given at the neck of fibula and the third stimulus was given laterally in poplitial

Table 1: Clinical and Electrophysiological findings.

\begin{tabular}{|c|c|c|c|c|c|c|c|c|c|c|c|c|c|c|}
\hline Cases: & 1 & 2 & 3 & 4 & 5 & 6 & 7 & 8 & 9 & 10 & 11 & 12 & Mean & SD \\
\hline Age (Years) & 24 & 18 & 19 & 45 & 23 & 18 & 28 & 35 & 25 & 16 & 18 & 19 & 24 & 8.5 \\
\hline Sex & $\mathrm{F}$ & M & M & M & M & M & M & M & M & M & M & M & - & - \\
\hline Handedness & $\mathrm{R}$ & $\mathrm{R}$ & $\mathrm{R}$ & $\mathrm{R}$ & $\mathrm{R}$ & $\mathrm{R}$ & $\mathrm{R}$ & $\mathrm{R}$ & $\mathrm{R}$ & $\mathrm{R}$ & $\mathrm{R}$ & $\mathrm{R}$ & - & - \\
\hline Height (cms) & 152 & 173 & 168 & 160 & 162 & 167 & 172 & 171 & 162 & 167 & 161 & 180 & 166.25 & 7.39 \\
\hline Weight (kg) & 52 & 69 & 53 & 66 & 54 & 55 & 65 & 72 & 58 & 52 & 67 & 65 & 60.67 & 7.37 \\
\hline No. of days Harvesting & 10 & 12 & 15 & 11 & 12 & 15 & 11 & 15 & 16 & 20 & 12 & 10 & 13.25 & 2.99 \\
\hline $\begin{array}{l}\text { Average continuous work } \\
\text { per day without a break } \\
\text { more than half hour }\end{array}$ & 5 & 7 & 6 & 8 & 8 & 7 & 6 & 5 & 5 & 5 & 6 & 7 & 6.25 & 1.14 \\
\hline Side of footdrop (L/R/BL) & $\mathrm{R}$ & $\mathrm{L}$ & $\mathrm{R}$ & $\mathrm{R}$ & $\mathrm{R}$ & $\mathrm{R}$ & $\mathrm{R}$ & $\mathrm{R}$ & $\mathrm{R}$ & $\mathrm{L}$ & $\mathrm{R}$ & $\mathrm{R}$ & - & - \\
\hline 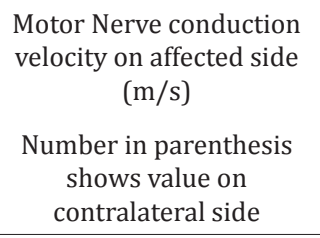 & $\begin{array}{c}34.02 \\
(45 . \\
16)\end{array}$ & $\begin{array}{c}37.15 \\
(45 . \\
41)\end{array}$ & $\begin{array}{l}\text { NR } \\
(44 . \\
28)\end{array}$ & $\begin{array}{c}29.38 \\
(35 . \\
55)\end{array}$ & $\begin{array}{c}53.18 \\
(52 . \\
19)\end{array}$ & $\begin{array}{c}45.12 \\
(44 . \\
41)\end{array}$ & $\begin{array}{c}27.33 \\
(35 . \\
75)\end{array}$ & $\begin{array}{l}\text { NR } \\
(43 . \\
34)\end{array}$ & $\begin{array}{l}\text { NR } \\
(42 . \\
26)\end{array}$ & $\begin{array}{c}40.46 \\
(47 . \\
98)\end{array}$ & $\begin{array}{c}32.46 \\
(42 . \\
24)\end{array}$ & $\begin{array}{l}\text { NR } \\
(46 . \\
12)\end{array}$ & $\begin{array}{l}24.93 \\
43.72\end{array}$ & $\begin{array}{c}19.65 \\
4.63\end{array}$ \\
\hline $\begin{array}{l}\text { Amplitude of motor nerve } \\
\text { conduction }(\mathrm{mV}) \\
\text { Number in parenthesis } \\
\text { shows value on } \\
\text { contralateral side }\end{array}$ & $\begin{array}{c}1.7 \\
(6.2)\end{array}$ & $\begin{array}{l}0.24 \\
(6.1)\end{array}$ & $\begin{array}{c}\text { NR } \\
(7.4)\end{array}$ & $\begin{array}{c}1.4 \\
(6.8)\end{array}$ & $\begin{array}{c}4.6 \\
(7.2)\end{array}$ & $\begin{array}{c}3.6 \\
(8.4)\end{array}$ & $\begin{array}{c}0.9 \\
(6.8)\end{array}$ & $\begin{array}{c}\text { NR } \\
(6.8)\end{array}$ & $\begin{array}{c}\text { NR } \\
(7.2)\end{array}$ & $\begin{array}{c}1.6 \\
(6.3)\end{array}$ & $\begin{array}{c}0.9 \\
(7.2)\end{array}$ & $\begin{array}{c}\text { NR } \\
(7.8)\end{array}$ & $\begin{array}{l}1.24 \\
7.02\end{array}$ & $\begin{array}{c}1.5 \\
0.67\end{array}$ \\
\hline $\begin{array}{l}\text { Distal Latency of motor } \\
\text { nerve conduction (ms) } \\
\text { Number in parenthesis } \\
\text { shows value on } \\
\text { contralateral side }\end{array}$ & $\begin{array}{c}9.48 \\
(6.78)\end{array}$ & $\begin{array}{l}11.67 \\
(7.2)\end{array}$ & $\begin{array}{c}\text { NR } \\
(6.58)\end{array}$ & $\begin{array}{l}11.56 \\
(9.69)\end{array}$ & $\begin{array}{l}10.31 \\
(6.34)\end{array}$ & $\begin{array}{c}9.58 \\
(4.48)\end{array}$ & $\begin{array}{l}15.52 \\
(8.28)\end{array}$ & $\begin{array}{c}\text { NR } \\
(5.56)\end{array}$ & $\begin{array}{c}\text { NR } \\
(4.82)\end{array}$ & $\begin{array}{c}12.6 \\
(6.43)\end{array}$ & $\begin{array}{c}6.35 \\
(3.98)\end{array}$ & $\begin{array}{c}\text { NR } \\
(5.26)\end{array}$ & $\begin{array}{l}7.26 \\
6.28\end{array}$ & $\begin{array}{l}5.77 \\
1.63\end{array}$ \\
\hline
\end{tabular}

The farmers were between 16 and 45 years of age with a mean of 24 years. Eleven farmers were male, while one farmer was female. All of them were right handed. Mean height of the study group was $166.25 \pm 7.39 \mathrm{cms}$ and mean weight was $60.67 \pm 7.36$ Kg. The farmers were doing harvesting for the past 10 to 20 days $(13.25 \pm 2.99)$. They were continuously working 5 to 8 hours per day without a break of more than half an hour $(6.25 \pm 1.14)$. Out of the twelve farmers, ten were having foot drop on right side, while two were having it on the left side confirmed by neurological examination. Electrophysiological recording on affected side was done on all of them, but failed to elicit any recordings in four farmers, showing complete peroneal nerve damage in these cases (In these cases recording electrodes were placed distally at extensor digitorum brevis and stimulus was given from proximal sites). But when the recording electrodes were placed proximally fossa. An informed consent was taken from all the patients before conducting the examination over them.

\section{Results and Discussion}

In our study we examined twelve farmers of foot drop for peroneal nerve injury due to prolonged squatting and walking in squat position in the uneven fields for harvesting of wheat crop. Clinically other causes of peroneal nerve injury resulting in footdrop were excluded. Clinical and electrophysiological findings are depicted in Table 1. 
nerve lesion. Moving one step ahead, we can also make prognosis of the disease and pathophysiology behind it [2]. The involvement of the peroneal nerve can be established electro physiologically if any one of the following criteria is fulfilled. Either there is complete absence of recordings of peroneal nerve or amplitude below $6 \mathrm{mV}$ on stimulation at fibular neck or NCV is less than $40 \mathrm{~m} / \mathrm{s}$.

In our study, we found that distal motor latency was significantly increased, while amplitude and conduction velocity were significantly decreased in the deep peroneal nerve on the side of foot drop. During harvesting season, a farmer has to adopt a particular pose for doing work due to the absence of advanced machinery. Here, they have to take a squatting position on the uneven ground, giving hyper dorsiflexion of ankle joint of mostly the dominant side and putting weight on same. They squat bending the dominant knee completely and the other knee partially. They make to and fro movement of the dominant hand to cut the crop because of this a continous friction is generated between dominant hand and the same side of knee on its lateral aspect, where peroneal nerve is superficial.

Whether peroneal nerve is injured due to hyper dorsiflexion of the ankle joint or complete knee flexion or repeated friction to the fibular head made by the moving arm, remains a question of debate.

\section{Conclusion}

By this study, it was concluded that peroneal neuropathy is the most common cause of footdrop in farmers doing harvesting manually. Though the most common site of peroneal nerve lesion is at fibular head in the knee joint, sparingly it can be injured at the ankle joint also. Our suggestion is that further investigations may be carried out to know the cause of peroneal nerve lesion at the ankle joint and prophylactic measures must be taken to prevent peroneal nerve injury to prevent such cases.

\section{References}

1. Cruz-Martinez A, Arpa J, Palau F (2000) Peroneal neuropathy after weight loss. J Peripher Nerv Syst 5(2): 101-105.

2. Katirji MB, Wilbourn AJ (1988) Common peroneal mononeuropathy: a clinical and electrophysiologic study of 116 lesions. Neurology 38(11): $1723-1728$

3. Nagler SH, Rangell L (1947) Peroneal palsy which was caused by crossing the legs. JAMA 133(11): 755-761.

4. Liveson JA (1991) Peripheral neurology case studies in electrodiagnosis. $\left(2^{\text {nd }}\right.$ edn), FA Davis Company, Philadelphia, USA, p. 48-55

5. Haymaker W, Woodhall B (1953) Peripheral nerve injuries, Principles of diagnosis, WE Saunders Co, Philadelphia \& London, UK, pp. 287-230.

6. Goldner JC, Thomas JE (1969) Foot drop. GP 40: 89-96.

7. Lee HJ (2001) Compound nerve action potential of common peroneal nerve recorded at fibular neck: its clinical usefulness. Am J Phys Med Rehabil 80(2): 108-112

8. Smith BE, Litchy WJS (1989) Sural mononeuropathy; A clinical and electrophysiological study. Neurology 39: 296.

9. Sotaniemi KA (1984) Slimmer's paralysis-Peroneal neuropathy during weight reduction. J Neural Neurosurg Psychiatry 47(5): 564-566.

10. Ghaffarpour M, Dolatabadi A, Harirchian MH (2002) Footdrop in the farmers: a clinical and an electromyographical study. Acta Medica Iranica 40(4): 214-218.

11. Garg R, Arora KS, Bansal N, Gupta N, Kaur H (2012) Footdrop in the Farmers in Punjab: A Retrospective Electrodiagnostic Study. J Clin Diagn Res 6(10): 1653-1657
Creative Commons Attribution 4.0

International License

For possible submissions Click Here

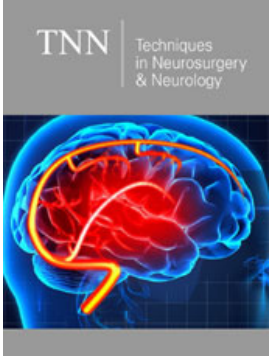

Techniques in Neurosurgery \& Neurology

\section{Benefits of Publishing with us}

- High-level peer review and editorial services

- Freely accessible online immediately upon publication

- Authors retain the copyright to their work

- Licensing it under a Creative Commons license

- Visibility through different online platforms 